\title{
Mompreneurs
}

Economics, Parenting and Identity

\section{Julie Landour}

Translator. Gabrielle Varro

\section{(2) OpenEdition}

\section{Journals}

\section{Electronic version}

URL: http://journals.openedition.org/travailemploi/10041

DOI: 10.4000/travailemploi. 10041

ISSN: 1775-416X

\section{Publisher}

DARES - Ministère du Travail

\section{Printed version}

Date of publication: 1 March 2020

Number of pages: 121-142

ISSN: 0224-4365

\section{Electronic reference}

Julie Landour, "Mompreneurs", Travail et Emploi [Online], Hors-série | 2020, Online since 01 March

2021, connection on 30 April 2021. URL: http://journals.openedition.org/travailemploi/10041 ; DOI: https://doi.org/10.4000/travailemploi.10041 


\title{
Mompreneurs
}

\section{Economics, Parenting and Identity"}

\author{
Julie Landour ${ }^{* *}$
}

\begin{abstract}
Mompreneurs is a movement that appeared in France towards the end of the 2000s. Its members define themselves as women who create a business when their baby is born, abandoning paid employment in favour of an independence supposed to insure a better work and family balance. The movement may seem insignificant when only the members of its "certified" networks are counted, but it involves deep and transversal processes of individuation, as well as the ongoing public celebration of individual economic initiatives and the stress put on parenting, particularly among the middle and upper classes. Based on three years of research carried out in one of the French Mompreneurs collectives, this article summons up these women's words, attempting to grasp - given the objective conditions of the independent professional activity they have chosen to practice - what they expected by giving up their salaried employment. After sketching the identity of an entrepreneurial adventure in the guise of "perfect mother", we will see how the family and its eventual fluctuations affect the life-courses of initially privileged women, revealing the part of fragility hidden beneath that promised, exalting, global enterprise of self.
\end{abstract}

\footnotetext{
Tn 1979, France saw the advent of Business Procedures Centres (Centres de formalités 1 pour les entreprises, CFE), ${ }^{1}$ of Assistance for the creative unemployed and business take-overs (Aide aux chômeurs créateurs et repreneurs d'entreprise, ACCRE), ${ }^{2}$ and the National Agency for Entrepreneurial Creations (Agence nationale pour la création
}

\footnotetext{
* Traduction: Gabrielle Varro. Article published in French in Travail et Emploi, no 150, 2017.

** Université Paris-Dauphine, IRISSO (UMR 7170), in association with the Center of Employment and Labour Studies (Centre d'études de l'emploi et du travail, CEET); julie.landour@dauphine.psl.eu.

1. As an interface between business creators and administrators, the CFE makes the first steps towards self-employment easier: https://www.service-public.fr/professionnels-entreprises/vosdroits/F24023, consulted January 27, 2021.

2. The ACCRE "consists mainly in exonerating a creator from paying into social security for one year and maintaining the social minima"; source: https://travail-emploi.gouv.fr/emploi/creation-ou-reprise-d-activite/, consulted January $27,2021$.
} 
d'entreprise, ANCE), ${ }^{3}$ all measures and institutions meant to enhance entrepreneurial activity in order to boost employment and growth. Since then, the successive governments have continued to promote employment, and their determination even increased considerably during the years 2000 , when a series of laws aiming to make creating a business simpler were voted in (DARBUS, 2008; ABDELNOUR, 2013). ${ }^{4}$ Though not directly targeted by those measures, women are one of the main objectives, since they count for approximately $30 \%$ of non-salaried workers. ${ }^{5}$ Institutional and professional decision-makers have multiplied the initiatives - charters, reports, collectives ${ }^{6}-$ to promote feminine business ventures.

The Mompreneurs Collective is one such initiative. Inspired by a movement that emerged during the 1990s in the United States, it appeared in France in 2008. Defining themselves as women who create a business when a baby arrives, the Mompreneurs began to come together via the Internet, by exchanging on blogs or on Facebook, then meeting informally in groups that quickly became volunteer associations all over the country. By claiming to be both a training and business development organisation for women company directors and businesswomen who refused to choose between their family life and their professional ambitions, ${ }^{7}$ they marked their resolve to be seen as a new professional group, and, by including the supremely feminine figure of the mother, seemed to be subverting the figure of entrepreneur, traditionally presented as male (AHL, 2004). ${ }^{8}$ But the mother figure was also transformed by an unprecedented connotation, in which motherhood triggers the realization that the stability of salaried employment must be foregone in favour of risking independence.

Basing ourselves on a three-year study carried out in one of the French Mompreneurs collectives (see Box), we will be considering, from a broad and materialistic point of

3. In 1996, the ANCE became the Agency for Business Creation (Agence pour la création d'entreprises, APCE), which then, in 2016, became the Agence France entrepreneur, AFE. To discover its missions, see: https://www.afecreation. fr/pid15040/qu-est-ce-que-l-agence-france-entrepreneur.html, consulted January 27, 2021.

4. We should mention, among others, the Dutreil laws of 2003 (law for economic initiative) and 2005 (law in favour of small and middle-sized firms), or yet again the law of 2008 that modernised the economy and set up the system of self-employment.

5. Including family help, they represented $31.5 \%$ of the non-salaried workforce (Employment survey [enquête Emploi], 2016).

6. Examples are: the "Charter for female entrepreneurship: 20 propositions to promote businesses created by women”( «Charte pour l'entrepreneuriat féminin: 20 propositions pour faire avancer l'entrepreneuriat féminin ») conceived by the Laboratoire de l'égalité in January 2013; the work in progress document by Claire Bernard, Caroline Le Moigne and Jean-Paul Nicolaï titled «L'entrepreneuriat féminin » (April 2013), published by the Centre d'analyse stratégique; the Awareness-raising week for the young on female entrepreneurship, launched in May 2013 by the Ministry of Women's Rights in collaboration with the APCE; and the upsurge of networks of female company directors, studied by Marion RABIER (2013) for her thesis in sociology.

7. See the website of the association, consulted January 2014. For reasons of confidentiality and to preserve their privacy, the exact address of the website cannot be divulged and the original formulations have been changed to limit the possibilities of precise identification.

8. Helen AHL produced a stimulating analysis of research bearing on "entrepreneurs": first, by reviewing the work of economists and management researchers, she accounts for the implicitly male quality that surrounds the description of the entrepreneur. Then, turning to work mainly carried out in the field of the managerial sciences, more particularly on businesswomen, she shows how gender relations have been revisited in research. 


\section{Box}

\section{Methodology}

This article calls on research carried out in one of the French Mompreneurs associations between 2011 and 2014. They appeared in France towards the end of the noughties (cf. supra), at the same time as the regime of auto-entrepreneur was created. Two separate organisations were founded by two socially privileged, though quite different, women. Very quickly, the two associations became rivals, one defending lobbying, the other mutual assistance among members (LANDOUR, 2015a). We will be studying the latter: at the time of the study, the association had nearly 500 members spread out in twenty regional subgroups. On the one hand, it was the most widespread Mompreneurs association in France and, on the other hand, one of the most numerically important networks of businesswomen in the country.

Our research methods combined several approaches: document analysis, observing various types of meetings (yearly conventions, monthly branch meetings, etc.), following up members' profiles and exchanges on Facebook, semi-directive interviews, carrying out a quantitative survey, etc. The 54 semi-directive interviews of the members of the Mompreneurs collective in the Île-de-France region $(n=37)$ and the Hérault region $(n=17)$, and the quantitative online survey of the entire association done between September 17 and October 6, 2013 (thanks to its membership file) are what contributed the most to the results presented here: 268 of the 417 women responded to the entire questionnaire, i.e. a rate of $64 \%$ return, with a sample closely resembling the profile of all its members.

view, ${ }^{9}$ this feminised form of non-salaried work, in which independence is considered the ideal way to combine work and family. We wish to enable the reader to hear the Mompreneurs speaking, to try and grasp the meanings they attach to independent labour, while exposing the objective conditions that prevail in the non-salaried professional activity they decided to pursue.

A first point, here, will consist in showing why creating an independent activity is deemed so precious by these formerly salaried employees, who felt prevented from engaging in their work as much as they would have liked: disappointed with or excluded from paid employment, they chose the entrepreneurial adventure along with that of accomplished mother. The second and third parts of this article will confront that dimension of their identity to their professional and more broadly socio-economic situation: several cases will permit seeing how, within a stable family context, a woman's occupation is pushed into the margins by an intensive, domestic and parental workload, to which they are personally committed as much as (re)assigned. In conclusion, we shall examine more closely the situations of those whose family structure is changing, particularly due to a separation or divorce: that is when the objective, individual

9. Following e.g. Christine DELPHY (1998, 2015), by “materialism” I mean the stress placed on the material conditions that surround a social fact, in particular the economic and social structures which surround its production. 
devaluation of these women appears, despite their privileged status, revealing the frailty of the promise underpinning their enterprise to be exalting, not only financially, but in the most intimate aspects of their lives.

\section{Self-Realisation Through Independence}

"We have resolved to create our activity in order to have more freedom and, above all, to balance our personal and professional lives": that is how the association's website presents Mompreneurs' "mindset". The rhetoric of the individual as master of his destiny is markedly present in the words of the women we met during the study. Though such rhetoric calls for further comment, it is also important not to sweep it under the carpet: it does in fact account for the sense that individuals make of their acts, and participates in the analysis of their positioning. This part of the article therefore returns to Mompreneurs' words concerning the professional trajectory that led them out of salaried work and into independence, by first exposing their "feminine" critique of salaried employment, then the meaning they attribute to actually exerting an independent professional activity.

\section{A Feminine Critique of Salaried Employment}

Though Mompreneurs present their access to independence as their own choice, their bifurcation nevertheless confirms their conspicuously compromised participation in the job market, as our quantitative survey showed: of our respondents, $28 \%$ had been unemployed before becoming Mompreneurs, half of them in long-term unemployment, a clearly higher ratio compared to all women aged 25 to $49(9.1 \% \text { in } 2015)^{10}$. Also, $8 \%$ had no professional activity and $2 \%$ said they were students. Besides, those who had a contract with a salary were not systematically at work: the $65 \%$ who were had just returned from a maternity or parental leave, ${ }^{11}$ but $9 \%$ were still away on maternity and $15 \%$ on parental leave. Lastly, of the 205 women who really became self-employed after having occupied a paid job, $24(11 \%)$ were approaching the end of a short-term contract (CDD, temporary work, etc.) and $96(47 \%)$ had signed a breach of contract by mutual consent. ${ }^{12}$

In fact, of all the respondents, only $40 \%$ had occupied a paid job before going independent; this echoes the difficulties encountered by women seeking to enter the

\footnotetext{
10. Source: INSEE, enquête Emploi 2015.

11. In 2010, $28 \%$ of mothers whose children were under 8 stopped working for at least one month by taking a full-time parental leave, while 21\% worked part-time (source: enquete Emploi, annex on work and family balance 2010). Though the figures do not exactly correspond to those we obtained, they seem to indicate that Mompreneurs take parental leave less often than the overall female population.

12. The fully accepted and favourable nature for the employee of this sort of breach of contract was challenged from the start in the first evaluations (BERTA et al., 2012; DALMASSO et al., 2012).
} 
labour market (MARUANI, MERON, 2012), particularly after one or several pregnancies (Meurs et al., 2010; Pailhé, Solaz, 2006, 2012; RÉGNier-Loilier, 2009), but, in light of the Mompreneurs' social characteristics, it deserves closer examination. For, although quite diverse, these women form on the whole a privileged group: according to the categories of our survey, $55 \%$ declared that, in their previous jobs, they were engineers, managers, directors or self-employed, and therefore fell into the higher categories; ${ }^{13} 23 \%$ declared that they belonged rather to the intermediate classes (supervisor, technician or similar) and $22 \%$ to the lower classes (worker or similar, office worker, sales or service personnel). Therefore, Mompreneurs would be three times more numerous in the higher categories than the entire national female population in France (17\% in the 2008 census). We might add that their favourable situation is even reinforced by their conjugal configuration: $86 \%$ live in a couple and $77 \%$ are married. ${ }^{14}$

Such diverse situations introduce nuances in the ways these women relate to salaried employment. Some never managed to hold a job in any permanent or satisfactory manner: it was so with Nathalie, the daughter of a skilled labourer and a stay-at-home mother, whose "destiny was not brilliant" when her husband left her. Nathalie, who sought to differentiate herself from her family milieu by her fervent dedication to the arts and letters, registered in a literary programme at university but, not well equipped to succeed, "missed the boat" during her first year. She then launched upon a series of small jobs, married early and divorced rapidly, while at the same time entering a curriculum to become a professional in communications. With her technician's diploma (Brevet de Technicien Supérieur, BTS), she went to Paris and devoted herself to several cultural projects, but none that, despite all her efforts, ever allowed her to land a stable position. At 30, "morally and physically exhausted", while planning a baby with her second husband, an IT manager, she decided to give up salaried work and create her own, independent activity:

"I wanted to change my life. That meant of course having a baby, changing my occupation, stop being cannon fodder. I knew I couldn't get myself hired, I had no degree, I didn't want to go back to school, I wanted all that to stop, so I told myself, my chance might be to go independent."

(Nathalie, 38, Corporate Services Company [société de services aux entreprises], interviews July 24 and August 6, 2013)

Others, who originated from more privileged families and boasted more degrees, had no difficulty finding stable jobs (with open-ended contracts, contrat à durée indéterminée $[\mathrm{CDI}])$, frequently in a managerial capacity or an intermediate profession, or as employees. In those cases, what went wrong and prevented them from staying with it, were the mishaps that befell them during any working day, which could be of two kinds: either the company encountered economic difficulties and could no longer guarantee an otherwise satisfactory position: that was what happened to Florence, an

13. According to the modalities proposed in our study.

14. For further details, see LANDOUR, 2015a. 
all-round, self-taught manager in a small company near Paris. When she was laid off for economic reasons, she and her husband Hugues, whose professional career was more unstable, already had three children. She tells the tale:

"After I was laid off, [...], I said to myself: 'OK, what do I do now?' I thought of trying a VAE [Validation of Competences Acquired Through Personal Experience, validation des acquis de l'expérience], yeah, I think that's what it was, and Hugues has been telling me for years: 'Florence, open your own business, open your own business!' All of a sudden, I thought: 'Why not, after all?' My boss also asked me to create my own company so he could pay me to work for him, $[\ldots]$ so right then and there, I decided to be my own boss."

(Florence, 40, Corporate Services Company[(société de services aux entreprises], interview April 10, 2012)

But, more frequently among our interviewees, it was the women themselves who often already had children and could no longer put up with the fast pace linked to their managerial status. More often employed in large-scale companies, they were confronted to an organisation of labour which made no sense to them, and subjected to pressures that their bodies and minds could no longer handle. That is what Rebecca describes. A top executive in a large cosmetic firm, she was married to another top manager who already had two children of his own. The couple have three children in common. Rebecca, who comes from the petite bourgeoisie in the Paris area and has a master's degree in civil law, ran up against the competition that is typical in that sort of company - noting that it worsens with every new pregnancy - until her body gave up and made it impossible for her to continue on the job; she was away sick for several months and ended up negotiating an economic dismissal:

"There was a very rough meeting with the girl who was stealing my files [...]. I told her where to get off, she complained, there was a meeting with our marketing director and she treated me something terrible: she came out with all sorts of horrors, I stood up for myself and sent her packing, and then we went back to our office and she got all sweet and lovey, as she's always been with me because she's such a hypocrite, she says 'So you had a good holiday? [imitating a honey voice]', whereas we had just scratched each other's eyes out! It was unbelievable - I bugged. I burnt out.'

(Rebecca, 36, Corporate Services Company [société de services aux entreprises], interview 26 October 2012)

Lastly, others were well integrated in the workplace (with open-ended contracts and in positions that did not represent any particular hardship) but could no longer muster the energy that sort of job requires to find self-fulfilment. They start imagining ways to build somewhere else the means to a self-accomplishment that takes all the spheres of their life into account. Sonia is a good example: she was an executive secretary in a very large communications firm, her husband worked in a public company and they had two children. She was, all in all, pleased with her situation and her relations with her co-workers, but wanted to get ahead in the Company and, to that end, registered in several training schemes. But despite her requests and the backing 
of the director she worked with, "I was given to understand that I'd never be able to advance." Her mother's situation - a former dressmaker who was divorced and living a life of deprivation - incited Sonia to imagine a way to attain the professional responsibilities to which she aspired and at the same time create a job "made to order" for her mother. To launch her activity, she took advantage of the voluntary redundancy plan the Company had set up.

Behind these life-courses, a globally damaged relationship to salaried employment is discernible, which takes different forms according to these women's original social characteristics (qualifications, age, etc.), to how they fit into their jobs (type of company and economic viability of same, position occupied, etc.), and according to their conjugal and family situations. A critique of salaried labour equally appears, which they no longer see as desirable. That criticism, however, is more feminine than feminist: though the difficulties they encountered were largely linked to their inferior position within the system of social sex relations (the importance of qualifications to integrate in a workplace, horizontal and vertical segregation, productive and reproductive burdens, etc.), the women we questioned speak of them in terms which are too personal to allow them to interpret their situation politically. ${ }^{15}$ And, too, the supremacy they confer to their individual, personal case extends to the perspectives they envision for the business they are about to create.

\section{Independent Work As Self-Fulfilment}

In the wake of the difficulties experienced in salaried work, it happens that our interviewees sometimes fall into a black hole, i.e., withdraw for a shorter or longer period of time from all professional activity. Though they occupy without a doubt the more privileged precincts of French society, they consider work as a powerful vector for their own identities: their words constantly return to the loathsome figure of the housewife, and long-term unemployment is implicitly assimilated to a form of welfare, that they also severely criticize. Focalising on the importance of professional activity for one's identity is compounded by their intimate relationship with selfemployment: among Mompreneurs, $72 \%$ say they know one or several self-employed persons. More precisely, among them, relatives in independent occupations are clearly over-represented: their own fathers were in independent occupations nearly twice, and their mothers nearly three times more often than in the general population, as are their partners, among whom $16 \%$ were artisans, merchants or company directors $v s .8 \%$ of the active male population. ${ }^{16}$ These women therefore have the advantage of being plunged into an "entrepreneurial bath" - actually a way of life for those

\footnotetext{
15. We might add that the word "Mompreneurs" and its incompletely feminised form - in French, to be a feminine word it should end with the suffix -eures - have never been disputed. There is great ambivalence in discussions about feminism in general, and actual practices as observed show a strong impregnation of sexual roles. For further details, see LANDOUR, 2015b.

16. For more details, see LANDOUR, 2015a.
} 
who have independent families as well as partners. That socialisation contributes to transforming independence into the most enhanced way of exercising a profession and freeing oneself from paid work, criticised for sometimes being so exasperating. It must also be noted that the interviewees barely mentioned the social protection attached to salaried employment, or when they did, more often than not they attacked it - as e.g. retirement. In our quantitative survey, $56 \%$ declared they created their business to practise an activity corresponding to their values; $24 \%$ saw independence as a way of practicing their dream occupation: the activities they chose translate idealised visions of self-accomplishment.

In that way, some of them are seeking to reconnect with a sublimated form of work (DuJARIER, 2006) that mixes body, mind and feeling. Artisanal occupations in particular seem meaningful to them (OsTY, 2003), whether or not they are put into practice. Aside from the fact that, to be best performed, such occupations demand extreme virtuosity, they reconnect with quintessential feminine qualities such as meticulousness, organisation and taste (particularly in the case of fashion, whether in clothing, decoration or linked to the latest gastronomical trends), of which Laurence is an example: a former sales employee married to a police officer and mother of one child, she has been making jewellery for years. When she was laid off, she launched her activity and a brand-name to sell the creations she made by hand with "passion" and "enthusiasm", deriving great "pleasure" when seeking out various providers to look for the raw materials she needed, inventing new models and working on materials and objects. ${ }^{17}$

Another characteristic of the activities chosen by the Mompreneurs consists in wanting to help others ${ }^{18}$ - but not just any others. None of them, for instance, bifurcated towards the public health or social sector and none have joined a charity. Frédérique's case is typical of the determination to help "similar others": a teachers" daughter married to an IT executive, Frédérique was a secretary in a small business in the South of France, which dismissed her during the three-year parental leave she took when her second child was born. At the end of her leave, during which she had "really appreciated the time spent with her children", she decided to create a business which would allow her to stay at home, and rediscovered what, as a teenager, she loved to do: "What I did was write people's memories, individuals', family memories and all that, since I was 15 , I really liked that." She decided to become a public writer, but not in any social or legal capacity, which she saw as arid and uninteresting: "Things like justice, like..., talking about problems and all, that's not really my thing, I'm too..., well, anyway, you either feel it or you don't." These women therefore aim for activities that might be classified as "care", but a caring one might call "clean", for people who are not very far from their own situation - in other words, who are neither sick nor in any great economic or social need.

17. Cf. Jourdain, 2017, presenting the situation of female artisans.

18. Once again, a trait essentialised as feminine. 
Putting one's self forward, sometimes totally, is the main point of the activity they create, and some do not hesitate to make themselves the very object of their sales pitch. They then frequently give their own name to their activity. Mélanie, daughter of a pharmacist and a Spanish teacher, who declares she has always refused the "contractshackle" (CDI-cadenas) which, besides, she had great pains to obtain after her Master's degree in graphic identity, presents a very extreme version of self-accomplishment that practicing an independent activity allows. For example, she baptized her selfenhancement company "Richness of Self": her offer consists in accompanying independent workers in their communications, through collective training and periods of individual coaching aimed at "creating coherence" between one's personality and one's activity. But Mélanie's self-enhancement goes even further: laid off after a stormy relationship with her boss, she decided to create her own activity - at the same time, her partner died of a staggeringly rapid cancer. Though she remains relatively discreet on the subject, the various posts on her blog often mention the resilience she was capable of mustering after that tragic event. She even turned it into a proof of the quality of the advice she sells to the self-employed people she accompanies... of whom many are Mompreneurs:

"For a long time I told myself it was 'normal': life had been hard enough on me so that at least I should be serene in my business. But nothing is ever 'normal'. It has nothing to do with my lucky star or optimism or self-esteem. In this world, where it's good form to say that the crisis is everywhere, my business and my life are really good. Even when my life was hell, my business was good. Why, and why me? Someone said not long ago: 'It's unbelievable, with all the catastrophes you've been through, you always manage to transform things so they go your way.' Surely, it's because I don't think in terms of business plans, targets, obstacles or difficulties; that vocabulary's foreign to me. That doesn't mean it doesn't exist. It means I see things differently."

(Excerpt from Mélanie's blog, published April 9, 2015)

The work they achieve as independent workers is therefore mainly thought of in terms of self-accomplishment. Mompreneurs' professional bifurcation in many ways recalls the conversions analysed by Pierre BOURDIEU among members of the "new petite bourgeoisie" (1979, pp. 409-421), principally its female members. They aim for new professions, on the border between the private and public spheres, where selfexpression and self-presentation are key. Mompreneurs usually have more diplomas than their parents (as a result of mass education) and are more economically active than the women studied by P. Bourdieu, they share an appetite for culture and domestic ethics, and are enthusiastic consumers. Starting a business - in the sense of creating an activity - is in their eyes a factor that sets them apart, facilitating a greater amount of self-expression and "authenticity", where taking risks is more prestigious than paid employment, which they often see as anaesthetising. Mompreneurs disdain the instrumental sides of work (remunerations, various social protections, etc.), the more as they are masked both by a psychological vision of social relations and a conjugal security that dilutes the autonomy of resources and what each partner contributes to 
the household. When analysing Mompreneurs' stories, their family circumstances must be particularly taken into account, not only because independent work is in fact an economic-family structure, but also because parenting is an absolutely central part of that work.

\section{Professional, Parental and Domestic Commitments in Competition}

As their name indicates, Mompreneurs assert their resolve to place work and motherhood, professional and parental commitments, on equal footings. ${ }^{19}$ To understand it, it is necessary to look closely at what parental and more especially maternal commitment implies, that makes the category unprecedented, even though mothers at the head of independent activities are an ancient and well-documented reality. The first part of this section concentrates on the ways Mompreneurs manifest their parental commitment by word and deed. In the second part, we describe its consequences, i.e. the dynamics of being reassigned to the domestic sphere.

\section{A Demanding Conception of Parenting}

Our interviews and observations permitted us to collect the various components of the parenting Mompreneurs actually do. At first determined to assert their professional existence, they do not give motherhood a central place in their discourse, whereas it is definitely central in their life-course. The fact that the women who had difficulties to become mothers are over-represented in the survey casts light on the subject. Carole, who has a degree in real-estate business law and is married to a CEO specialized in IT, adopted a child. Though during her interview, she insisted above all on her professional commitment, she admits that adoption was an obstacle course that governed her entire life, even to make her quit her job. After accumulating unpaid holiday time during the adoption procedure, then a parental leave when her child arrived four years later, she can no longer put up with "being able to see her daughter only twenty minutes a day". Parents' - more particularly mothers' - availability is in fact at the heart of these women's definition of what parental work entails (LANDOUR, 2016).

\footnotetext{
19. We prefer using the term parental rather than maternal, based on the idea that all the tasks listed under the term "parenting" can be done indifferently by a man or a woman (aside for the work connected to pregnancy and giving birth per se). That those chores are more often done by the mother or the father remains to be seen according to the results of the study and must be analysed like a social fact in its own right. We therefore consider that parenting signifies everything that adults do around their child. We include health work (feeding, care, etc.), but also education (e.g. learning good manners), schooling (supervising homework) and everything that, concretely but also mentally, comes under the concept of caring for a child. Parenting evolves over the different stages of life, marked by institutionalised levels and places (entering school and its various rhythms), and by more or less predictable events (evolution of the family framework, etc.). We might add that parenting can also be carried out by adults other than the parents (other members of the family for example, or professionals such as mothers' helpers or childcare assistants).
} 
Beyond the words employed, the obligation to be available, which is part of the Mompreneur ethic, impacts their itineraries to a great extent. When the children are small, for instance, the various sorts of care a child demands require a greater or lesser amount of physical and mental availability. The most time-consuming chores figure regularly in Mompreneurs' narratives: giving birth at home, carrying the baby in a scarf, sharing the bed with the baby, prolonged breastfeeding (sometimes until age two) and other nurturing and care procedures (washable nappies, home-made baby-food, etc.). Then, later on, being there for the children can also become very necessary, especially where school is concerned, as we saw earlier in Frédérique's story. Despite having been laid-off, she claims she had a "wonderful time" with her children during her parental leave, being able to give them lunch, keeping the youngest at home in the afternoon, or participating in the school parents' association. During her interview, when she listed all the activities she had organised for her children, she pointed out the cases of mothers who seemed not to feel obliged to do the same for theirs:

"You've got mothers who stay at home and don't know what to do with themselves, that's true too. I have a chum who's a house mom and she counts the days until the next vacation. She'll say: 'Another week to go.' When you hear that you think, alright, it's true she likes being at home but at the same time, her kids drive her mad. On top of that she's not one for walks or outings, so they don't know what to do with themselves either, and when that happens..."

(Frédérique, 39, Corporate Services Company [société de services aux entreprises], interview June 11, 2013)

Frédérique blames the laziness of some stay-at-home mothers, whom she tries not to resemble, but she is equally critical of the mothers who have remained active, who "don't know how to stop", even for a "salary that's not so great", blaming their lack of availability for their children. The pleasure she gets from being with her children - also a distinguishing factor compared to other mothers - is what prompted her to resume an independent activity, which was both gratifying and could be adjusted to the complete and dense personal presence she wanted for her children:

"That's the side... I have a professional activity to develop, it's my thing, straight out of my gut, it's my desire. I really want to do everything it takes to make it work and it will work because I believe in it so much it can't fail, and at the same time I have children and I want to manage it all at once: but my children mustn't suffer from my absences, I must be there for them because that's what I like, to fetch them at lunchtime so we can eat together, I fetch them at school at 5, I love going to their shows. I love it all and I am all that at the same time. I'm an available mom and I'm the girl who creates her own professional activity too!"

(Frédérique, 39, Corporate Services Company [société de services aux entreprises], interview June 11 2013) 
Parallel to creating an economic business, which as we have seen, also expresses their identities, by their involvement in intensive parenting, Mompreneurs are at the head of a parental enterprise too. Though the latter is structured round child-centred activities (GARCIA, 2011), the women use it to distinguish themselves from other mothers (LANDOUR, 2016). These life-courses are therefore the end-result of a global business of self (entreprise globale de soi) (EHRENBERG, 1991), and the salary setback is apparently cancelled out by an individual initiative that no longer concerns work alone but the family as well and more broadly everything in the personal domain. Nevertheless, socially speaking, the initiative does not always prove absolutely successful. In particular, for the observer with a materialistic set of mind, Mompreneurs' dual commitment has very real consequences for their life-course: it triggers a greater assignation of these women to the sphere of domesticity.

\section{A Global Throwback to the Domestic Sphere}

Engaged in an independent activity, aimed above all at self-fulfilment, Mompreneurs simultaneously deploy an intensive form of motherhood (HAYs, 1996), in the shape of a strict mothering which has itself become a source of social positioning. If it can be taken for granted that the job of parenting, though it may be visible outside the home, is done mainly in private, our survey shows that $74 \%$ of the Mompreneurs practice their professions at home. True, that fact must be connected to the weakness of their initial investment: of the $66 \%$ who say they invested less than 8,000 euros, $45 \%$ invested less than 2,000 and 48\% between 2,000 and 4,000 euros. By investing mainly their personal and family savings to create their activity (only $20 \%$ claim to have asked for a loan and only $11 \%$ a bank loan), Mompreneurs do not dispose of much room for maneuvering, which does not allow them to invest in another workplace than their own home.

Mompreneurs tend to attach great value to working conditions that permit them to work while watching their children, especially when they are babies, supposed to sleep all the time. In fact, many of them indicate that they find it impossible to really focus on their work when the children are there - the fathers are for the main part absent during the day; that is what Lili explained to us. A graphic designer who "loved corporate life", Lili was forced to accept a breach of contract right before becoming pregnant and moving into the Greater Paris area with her husband, a clothing store manager. Her former employer gave her occasional assignments, which incited her to become self-employed during her pregnancy, a status that became permanent "somewhat by chance", depending on the contracts that turned up. After her baby was born, she tried to work from home but found it difficult to juggle everything at once, because the fact she couldn't take care of the baby in spite of being in the same house with it was contrary to her principles and how she wanted to raise her child:

"Last year was really awful. I had done my accounting and she stayed one and a half hours alone in her playpen, all alone: she was playing but I don't want a rump 
child, I don't want to leave her sitting alone in her pen. What I like best is painting with her, but I like a lot of other things too, playing, reading, singing songs, I want her to be lively and awake, I'm not going to set her in front of the telly, that doesn't interest me one bit."

(Lili, 32, Corporate Services Company [société de services aux entreprises], interview June 23, 2012)

As we saw above with Frédérique, Lili wants to stimulate her child, and that depends on being constantly present to multiply the number of awareness-raising activities. She is therefore incapable of fulfilling her parental obligations while working and had to resign herself to leaving her daughter with a "nounou", at first part-time, then full-time, when her child was only five months old but she too was obliged to work full-time. ${ }^{20}$ But it was never really a full-time: her spouse looks after the little one on Wednesdays, but, as Lili explained, she found it terribly hard to work with the whole family there. Aside from parenting, Lili is also for a large part responsible for the household: her partner takes care of the shopping but she does the laundry (a very demanding chore when there is a baby), keeps the house in order and does the rest of the housework. When she asked her partner to help more, he suggested they take on a cleaning lady two hours a week. But Lili feels guilty and always makes sure the apartment is in good shape before the cleaning lady arrives:

"It doesn't seem like much because she only comes for two hours, but for her to be able to clean, everything's got to be put away, because she's not supposed to do that. So you're obliged to put everything more or less back in place, to keep things in order. So in the end, when she comes, it's really to do the cleaning, whereas when $I$ do the cleaning, I put things away at the same time."

(Lili, 32, Corporate Services Company [société de services aux entreprises], interview June 23, 2012)

We should stress that, contrary to what the notion of reconciling the different spheres of life suggests, superimposing the professional and family domains does not at all go without saying. By setting up their activity in a space shared with the entire family, Mompreneurs are also forced to give the family, when they are present, access to that space, which is also theirs: before opening up her shop and her laboratory, Caroline, formerly a manager in the Paris Region, married to a logistics engineer, launched into the food trade, transforming "her house into a factory". She invested in specific equipment such as "a progressive cooling oven, a cabinet she had made to order for the house, exchanged the drawing room tables for market tables that fold up when there's a lot of volume to deal with", or transformed the office into a "store room" and the washroom into a "cold-room". Not only "our home" was "no longer home!", the way the space was organised impacted the rhythm of the work as well:

20. Contrary to Frédérique, Lili's partner worries about their couple's economic situation and forces her to keep up a lucrative activity, particularly so as to contribute to reimbursing the loan they took to buy the apartment. 
"Beginning at 5:30, everything gets put away, the table is cleared and cleaned, the whole kitchen is cleaned, the cakes are piled up so we can eat later on, etc., we go pick up his son, etc. and if the cakes aren't finished, we pull everything out again at 9 and finish at 11 p.m."

(Caroline, 33, in the food trade, interview July 16, 2013)

Since their activity takes place mainly in the home, Mompreneurs' work tempo is impacted, both as to its continuity, and in terms of duration: while $61 \%$ of those working at home work at least a 30-hour week, it is the case for $79 \%$ of those working away from home. Those who answered our quantitative survey have on the whole significantly shorter working weeks than the independent workers: $27 \%$ of the Mompreneurs declare more than 40 hours a week; $19 \%$ between 35 and 40 hours, i.e. equivalent to a full-time; $46 \%$ less than 35 hours (part time). Among the latter, 30\% work the equivalent of a part-time job or less, $43 \%$ more than a part-time but less than four-fifth time, $27 \%$ between a four-fifth and 35 hours. The Time Use surveys (enquêtes Emploi du temps) reveal that the category of independent workers has the longest working time (6 hours 51'vs. 5 hours 16' a day on average, i.e. nearly 47 hours a week) ${ }^{21}$ both their free time and the time spent on domestic work are reduced, this last variable demanding further scrutiny according to gender. ${ }^{22}$ Finding themselves thrown back into domesticity, Mompreneurs seem on the whole to give themselves less to their professional time than independent workers do.

\section{Maternal Independence, Between Economic Risks and Downward Social Mobility}

Though being available for their children and self-accomplishment are the Mompreneurs' priorities and markers of their identities, they nevertheless are obliged to consider their social and financial situation. Behind their words, we will be examining more closely the economic consequences of their itineraries as Mompreneurs, by attempting to identify the different levels of "success". A case by case assessment shows that these strata are masked by a privileged conjugal situation, so that it is difficult to determine which partner, in the couple, provides more income and protection. ${ }^{23}$ Since Mompreneurs in their couple are not spared by the need to negotiate, nor by the reconfigurations that affect the contemporary family today, in this last part we will be looking at the consequences that the eventual loosening of family ties might generate for the social and economic situation of these originally rather privileged and protected women.

21. Source: INSEE, Time Use survey 2009-2010.

22. See the article by Amandine BARROIS and François-Xavier DEvETTER (2017) for an in-depth investigation of the working time of independent female workers.

23. We did not have access during the study to the details of couples' incomes. However, in most of the cases, one guesses that the male partner is the main financial provider. 


\section{Rival Commitments that Undermine the Economic Perspectives of a Business}

During the vast movement promoting individual economic initiatives and selfenhancement that has swept over France since the end of the 1970s, the media have often put the accent on the access to financial responsibility, that creating a non-salaried activity such as the Mompreneurs' seems at first sight to signify. But what really is the case? In order to evaluate the Mompreneur category from an economic point of view, we have decided to apply two principles: we ask ourselves first if the activities they created allow them to pay themselves an individual salary (where pertinent, this takes into account their unemployment benefits); we then examine the level this income represents and the protections it entails.

Our quantitative data call for several remarks: of the 268 women who responded, 194 declared an annual turnover of less than 15,000 euros; 72\% thus pay themselves a monthly salary that a priori falls below the monthly minimum wage for a full-time job (Salaire minimum interprofessionnel de croissance, SMIC, i.e. 1,480 euros). ${ }^{24}$ Among them, 40 (21\%) had created their activity more than two years before our study and were therefore not eligible for the dole (limited to twenty-four months for the under 50 years old). Forty-four women (16\%) declared an annual turnover above 30,000 euros. Between those two extremes, only $10 \%$ of our respondents declared a yearly income that oscillated between one and two Smics (not subtracting the various employer costs involved). Between representing a little more "butter on your bread" and a certain degree of economic affluence, very contrasting financial situations exist among the Mompreneurs, which depend on several factors. Two cases - Christelle's and Marion's - permit us to spell them out more clearly.

Daughter of a serial entrepreneur and a mother executive in interior decoration, partner of a cash-flow specialist with whom she had two children, Christelle rose to an executive position in a firm of the paper industry that "interests her immensely". She missed out on a promotion and, when she asked what the reason was, was told it was because she only worked part-time; she "exploded" - but as member of the Health and Security Committee of the company, where she had been working for approximately six years, she managed to negotiate a painless dismissal. Determined to create a family e-commerce in the paper sector, in which her partner - on the dole at the time - could work too, she obtained a training scheme in the conception and management of websites. While he found a new job, Christelle continued setting up her business in the refurbished garage of the house they own: importantly, she became a member of a production cooperative (Société coopérative de production, SCOP), keeping in touch with her former clients and suppliers. She reinforced that professional base by adding a web-indexing activity, for which she worked very seriously, even to obtaining a certificate. By having her various resources - professional, institutional, organisational and domestic - fructify, she could declare a turnover of

24. See https://www.urssaf.fr/portail/home/taux-et-baremes/smic.html, for updated amounts, consulted January 27, 2021. 
over 100,000 euros per year, that her lifestyle confirms (she owns a new SUV, tells of her many trips abroad, etc.). When she began creating her activity, Christelle was already a mother for several years and, though it is she who largely runs the household, she delegates part of the housework to a cleaning lady and shares many parental tasks with her partner. Getting him, for whom the entrepreneurial project had been intended in the first place, to participate, is also a contributing factor to its financial success.

In her thirties and mother of a little girl, Marion left her native town to settle in the South of France, far from her parents and especially from her father, an artisan (a characteristic, as we have seen, of the Mompreneurs, whose parents were often independent workers themselves). She and her partner found it difficult to land a stable job in the region, which has a high level of unemployment. After a first attempt at creating a cultural activity as a couple, Marion, then pregnant, landed a permanent (CDI) job in a small local company. But work relations there were vile and, even though she was elected personnel representative with a colleague to whom she was close, both women had trouble resisting the pressures placed on them. Determined to leave the company come what may, they ended up accepting a breach of contract negotiated a minima. Caught up in parenting with her daughter and claiming that she loved drawing since she was a little girl, Marion decided to self-publish two volumes of children's stories with her friend; an agency of the Unemployment Bureau directed them towards a business incubator specialized in art, which provided them with a legal structure as well as a technical assistance in accounting. The two friends, who lived on their unemployment benefits, put up the 3,000 euros out of their own pockets and published two albums without having to ask for a loan. One and a half years later, of the 2,000 volumes printed, they had sold 400 (300 of the first album) and still had to bring in 1,000 euros to recover their upfront investment. On the economic front, the project was a failure, meaning that when their contract with the incubator came to a halt in November 2012, it was no longer possible to dream of going independent with that activity. At the same time, in 2013, Marion's two years of unemployment benefits ended, forcing her to find an income urgently. During the interview, though she continued to highlight her nonsalaried project, she said that she had in fact never stopped looking for a job, without being able to secure a single contract, given the limited number of offers in the region. Her entourage tried to help: her aunt, for example, used her network of acquaintances to get her contracts in computer graphics. In order to be able to emit invoices, Marion registered as an auto-entrepreneur in January 2013, but her activity remained limited (she declares she had practically no work at all during the first three months of the year) and her contracts depended largely on personal connections ("things start rolling between April and May, above all thanks to people I know, friends, family, friends of the family"). She feels that the month preceding our encounter (May 2013) was her best, because she managed to glean an "almost satisfactory salary". 
"Between the little I paid myself out of the association, a mission and a few little orders on the side, I must have earned 1,400 euros, which was good for a start, because I had only begun very recently."

(Marion, 32, self-employed, Corporate Services [services aux entreprises], interview June 17, 2013)

Marion does not dispose of the same resources as Christelle (she is not married, for example), and she cannot count on the financial support of her entourage. It is true that her partner, who had inherited from his family, was able to buy cash the house where the family lives; however, Marion's professional situation remains shaky.

There are therefore very different situations among the Mompreneurs, from objectively comfortable circumstances backed up by considerable resources intensively capitalized, to cases that are clearly more uncertain on the individual level. But those differences are masked by their life as a couple: Marion, for example, claims she can live comfortably with 1,000-1,500 euros a month, because she benefits from her partner's income and property. But what happens when these women lose their family's support?

\section{When the Family Is No Longer a "Common Cause"25}

The longitudinal survey permitted us to see how the situations of the Mompreneurs we met evolved, for better or for worse. Several of them testify to failures of various sorts. It sometimes happens that an independent activity comes to a halt; some Mompreneurs went bankrupt, particularly those who had launched a commercial activity and found themselves with unsold stock on their hands and suppliers they could no longer pay. That is what happened to Delphine, married to a public servant, herself a former executive in a service company. After being laid off, she created a limited liability company (Société à responsabilité limitée, SARL) in the para-pharmaceutical sector: parallel to creating her e-commerce website, she fixed up a room in the family house where she hoped to organize olfactive workshops. One and a half years after our first meeting, she admitted her activity was not as successful as she had hoped, which greatly preoccupied her partner; in reaction to his worries, she took a job as part-time salesperson in an organic store close to their home. She explains she had decided to put an end to her activity and had looked again for a paid job, but after several rebuffs for executive positions, she ended up accepting a job as sales assistant at four-fifth time in a very small local firm.

Though Delphine no longer enjoys all the benefits of salaried employment, she remains protected by her family situation, despite marital difficulties to which she alluded discreetly. In other cases, however, when the family falls apart, for instance, it is the woman's freedom itself which is called into question, as Barbara's case will allow us to see. She is nearly 50 and has a little boy 8 years old. Daughter of an engineer

25. See Roy, 2005. 
and a stay-at-home mother, amateur dancer, she tried to enter the world of dance, without success. She then worked as hostess in several haute couture salons, until she met a businessman established in the South of France. She became his partner and collaborator for several years, with no status, either conjugal or professional; when he died, her situation became very hazardous: she lived for several years on the welfare allowance known as the active solidarity income (Revenu de solidarité active, RSA). Then she met the "father of her son", an independent IP engineer. During her interview, she lets fall the information that the child was a "miracle": at more than 40, desperate to become a mother, she decided to have a child even though she knew that "her couple wouldn't last very long". When the baby was born, the couple had already separated, but continued to live in the same house (that belonged to him). Barbara says she lived like a "bourgeoise in her home" for several years: while caring for her son, she took courses and followed several training schemes in psychology. She talks very calmly about her relationship with the father of her son, with whom she shares a house, as well as several bank accounts:

"One day he ordered a bank-card for me on his account and he gave me his card and since then I never gave it back and he never asked me to [...] and there is something, something natural in that, yes, even more so since I became a mother. In fact, it's as if it was my work and my salary to make sure there is enough to eat in the house, to take care of my son, that he should be well brought up [...]. And it is because he trusts me completely, and he can, believe me."

(Barbara, 48, independent company of services to individuals [services aux particuliers], interview June 11, 2013)

Consequently, she says she appreciates the "comfort" of her situation, finances not being "her problem". But several factors darken the picture: her parents are anguished because they feel she is in a "frighteningly precarious situation"; what is more, she now has trouble finding a new partner (the men she meets think her situation is "too weird"), and seems quite isolated in the education of her son, who does not seem to see his father much on a daily basis. As self-employed, Barbara also started an independent coaching activity, completed by gym classes. She hopes that developing that double activity will allow her to rent an apartment in a few months, a sign that she would like to get out of a situation which is not that comfortable after all. Though Barbara's case is in many ways atypical, it reveals the conjugal dependency of Mompreneurs who exert a not very - or even at all - profitable independent activity: it should be recalled that $72 \%$ of these women working full-time earn less than a monthly SMIC (minimum wage). The quest for self-realization which motivated them incites a good number, among the less privileged and those who were furthest from the world of independent work in the first place, to give priority to activities that are doubtless rewarding, but less remunerative than a paid job with a regular income. Behind the creation of a business, there therefore lurks the risk of an individual, economic downgrading, that the figure of entrepreneur covers up. In case of divorce, the women are extremely dependent financially on the solidarity of their ex-spouse, and it is well known that 
this never makes up for the comfort that living as a couple guaranteed and which is now lost (BONNET et al., 2015). Finally, in the long run, these women see their level of social protection, particularly as concerns retirement, reduced by the weakness of their turnover. ${ }^{26}$ Under cover of a global enterprise of self, a classical, gendered hierarchy remains effective, and even seems to deepen. Between work, market economy and family, the Mompreneur promise of attaining personal responsibility and being capable of reconciling all the spheres of life is more of a mirage than a miracle, including for the women who would have the necessary resources to mitigate their domination within the system of gender relations.

At the end of this study, it appears that entering the world of independence is, for Mompreneurs, an identity issue above all; it allows them to practice an activity that is more expressive than instrumental but also to develop an equally identity-ridden relation to parenting. Nevertheless, they are tightly relegated to the home, and it is only when they manage to activate the many and well-adapted resources which were theirs from the beginning, that some of them manage to achieve a relative stability, while others find themselves entirely dependent on their partner. On the whole, those who do not succeed in making their activity profitable enough to pay themselves an income, find that they have slipped downward on the social ladder; and those who, besides, see the support of their family and spouse waver are exposed to the risk of economic and social demotion in the longer term.

For all these reasons, the phenomenon calls into question several facts at the crossroads of work, family and public policy: the amplification of parental norms, which still for the main part target the mother, challenges the women's capacity to stand firm in a job requiring an ever higher level of performance. Creating a business, due to the apparent flexibility it augurs in the management of one's schedule, can of course be used as a system they had not anticipated to manage the different times of life. Nevertheless, Mompreneurs' trajectories show that a professional activity and parenting, even when carried out in the same place, are in reality more comparable than superposable. Mompreneurs also sharply question the public systems of activation, such as those conceived to stimulate the creation of an independent business, which demand mobilising the totality of an individual's resources: within this relatively privileged social group, those resources are not only collective - e.g. financial assistance to create a business or an offer of professional training - they also include the biographical capital of individuals predisposed to accept themselves as such. Concerning women

26. It should be remembered that, though independent workers' social benefits have gradually come to equal those of salaried employees, a minimal turnover is nevertheless required to validate their working time (in the French system, this time is calculated on a quarterly basis). For example, in 2017, to validate two trimesters, a service activity had to declare an income of 4,190 euros (source: https://www.rsi.fr/cotisations/ae/protection-sociale.html, consulted October 6, 2017, which no longer exists). 
specifically, studying the Mompreneurs reminds us that, within the system of gender relations, they remain trapped in an inferior position, which structures the way they relate to work, renewed by the job of parenting and legitimatised by the norms of parenthood, still today conjugated in the feminine form. Their capacity for individuation and emancipation is therefore all the more difficult to implement, even for the most privileged among them.

\section{REFERENCES:}

ABDELNOUR, S. (2013). «L'entrepreneuriat au service des politiques sociales: la fabrication du consensus politique sur le dispositif de l'auto-entrepreneur. » Sociétés contemporaines, 89, 131-154.

Aht, H. (2004). The Scientific Reproduction of Gender Inequality, a Discourse Analysis of Research Texts on Women's Entrepreneurship. Copenhague: Copenhagen Business School Press.

BARRoIs, A., DevetTER, F.-X. (2017). « Femmes salariées et non salariées : quelles différences de temps de travail ? » Travail et Emploi, 150, 101-130.

Berta, N., Signoretto, C., Valentin, J. (2012). «La rupture conventionnelle: objectifs officiels versus enjeux implicites? » Revue française de socio-économie, 9, 191-208.

Bonnet, C., Garbinti, B. and Solaz, A. (2015). «Les conditions de vie des enfants après le divorce. »Insee première, no 1536.

Bourdieu, P. (1979). La Distinction. Critique sociale du jugement. Paris: Éditions de Minuit.

DAlmasso, R., Gomel, B., MÉDA, D., and SERVERIN É. (2012). Des ruptures conventionnelles vues par des salariés. Analyse d'un échantillon de cent une ruptures conventionnelles signées fin 2010. Rapport de recherche, no 80, Noisy-le-Grand: Centre d'études de l'emploi.

DARBUS, F. (2008). « L'accompagnement à la création d'entreprise. Auto-emploi et recomposition de la condition salariale. » Actes de la recherche en sciences sociales, 175, 18-33.

DelPhy, C. (1998). L'Ennemi principal, tomes 1 et 2. Paris: Syllepse.

Delphy, C. (2015). Pour une théorie générale de l'exploitation. Des différentes formes d'extorsion de travail aujourd'hui. Paris: Syllepse.

Dujarier, M.-A. (2006). L'Idéal au travail. Paris: Presses universitaires de France.

Ehrenberg, A. (1991). Le Culte de la performance. Paris: Calmann-Lévy.

FouQuet, A. (2005). «Les femmes chefs d'entreprise: le cas français. » Travail, genre et sociétés, 13, 31-50.

GARCIA, S. (2011). Mères sous influence: de la cause des femmes à la cause des enfants. Paris: La Découverte.

HaYs, S. (1996). The Cultural Contradictions of Motherhood. New Haven, London: Yale University Press. 
Jourdain, A. (2017). «Des artisans d'art aux artisanes d'art. Ce que le genre fait aux métiers d'art indépendants. » Travail et Emploi, 150, pp. 25-52.

LANDOUR, J. (2015a). «Quand les mères deviennent entrepreneurs. Image et expériences des “Mompreneurs". » Sociétés contemporaines, 98, 137-168.

LANDOUR, J. (2015b). «Les collectifs de "Mompreneurs", une solidarité professionnellement porteuse ? » Modern \& Contemporary France, (23)4, 457-473.

LANDOUR, J. (2016). «La parentalité, une contribution au capital des femmes des classes supérieures ? » Genre, sexualité et société [online], 16: https://doi.org/10.4000/gss.3886.

Maruani, M., Meron, M. (2012). Un siècle de travail des femmes en France (1901-2011). Paris: La Découverte.

Meurs, D., Pailhé, A., Ponthieux, S. (2010). «Enfants, interruptions d'activité des femmes et écart de salaire entre les sexes. » Revue de l'OFCE, 114, 113-133.

Osty, F. (2003). Le Désir de métier. Engagement, identité et reconnaissance au travail. Rennes: Presses universitaires de Rennes.

Pailhé, A., Solaz, A. (2006). «Vie professionnelle et naissance: la charge de la conciliation repose essentiellement sur les femmes. » Population et sociétés, no 426.

Pailhé, A., Solaz, A. (2012). « Durée et conditions de retour à l'emploi des mères après une naissance. » Retraite et société, 63, 51-77.

RABIER, M. (2013). Entrepreneuses de cause. Contribution à une sociologie des engagements des dirigeantes économiques en France. (Thèse de doctorat en sociologie, École des hautes études en sciences sociales).

RÉGNIER-LOILIER, A. (2009). "L'arrivée d'un enfant modifie-t-elle la répartition des tâches domestiques au sein du couple ?» Population et sociétés, no 461.

Roy, D. (2005). « Tout ce qui est à moi est à toi ? Mise en commun des revenus et transferts d'argent dans le couple. » Terrain, 45, 41-52. 
